to say that the Pittsburg (Pa.) Christian Advocate formerly contained such advertisements. Some five or six years ago I corresponded with the editor regarding the matter and he expressed his dissatisfaction with the situation and referred me to the business manager. I do not recall how often I wrote the latter, but $I$ am sure $I$ called his attention to the fraudulent claims of some of the advertisements in the paper. For over a year now they have been discontinued. I do not know that my writing hastened matters, but I believe it contributed in a measure to the change. If all physicians who are readers of these religious papers would tale pains to protest repeatedly, all such periodicals would in time be cleaner in their advertising columns."

IIn his letter our correspondent has gone straight to the mark. Papers and magazines, whether religious, medical or secular, are like public officials, exactly what the public makes them. Reforms must come from the readers. They must not be expected to come from the business management. If the readers and subseribers of religious papers want religious journals which are free from deceptive and dishonest advertising, they can easily get them, if they will make the management of such papers understand their wishes.]

\section{Methods of Nostrum Vendors.}

The methods of the nostrum vendors have a remarkable similarity in foreign countries as well as here. Neustatter (Miinch. med. Wochschr., Sept. 25, 1906), calls attention to the efforts to mislead medical men made by the promoters of antipositin, the notorious nostrum which has been put forward with such extravagant claims as a means of reducing corpulence. He quotes a circular which refers to the important articles that have appeared in the medical press regarding the remedy. The shamelessness of this proceeding, says Neustätter, is shown by the fact that the articles which have appeared have warned against the use of the nostrum. According to the analysis of F. Zernik (A pothele-Zeitung, No. 81, 1906), this remedy consists of sodium citrate, 28.5 parts; sodium tartrate, 20 ; sodium bicarbonate, 18 ; sodium chlorid, 12; purified tartar, 9; tartaric acid, 6; dried carbonate of sodium, 6, and magnesia usta, 0.5. It would seem that the composition of the mixture has been changed since its first introduction.

\section{Correspondence}

\section{The New Infectious Disease.}

New York City, Feb. 2, 1907.

To the Editor:-Dr. Hirshberg, I fear, is not modest in claiming the credit of having discovered a new infectious disease (The Journal, Feb. 2, 1907, p. 416), and branding the work of those who long before him wrote on this subject as "so very obscure, faulty and incomplete." The paper of mine which Dr. Hirshberg quoted (Amer. Medico-Surg. Bull., Dec. 26, 1896), speaks of an epidemic of a "Peculiar Form of Hyperpyrexia" which I observed in 28 children under 14 years of age. The fever developed very suddenly, ranged between 104 and 106 F., continued almost uninterruptedly for from two to three and a half weeks, and ended either by crisis or lysis, leaving the children in apparently perfect health. The rapidity of the pulse and respiration varied with the height of the temperature. There were no roseola, enlargement of liver or spleen, diarrhea, delirium, insomnia, or headache. Some patients presented mental dulness and disturbance of hearing and speech. I strongly emphasized the fact (giving full details) that very careful bacteriologic and microscopic exam. inations of the stools, urine and blood proved the absence of malaria, typhoid or influenza. I also mentioned that postmortem examination of a tuberculous child who succumbed to this fever failed to show any lesions suggestive of malaria or typhoid. Finally I made an effort to differentiate this affection from several other similar fevers.

\section{H. B. Sheffield, M.D.}

The preceding letter was submitted to Dr. Hirshberg who makes the following reply:

Baltimore, Feb. 6, 1907.

To the Editor:-Dr. Sheffield takes a very unkind attitude toward the simple announcement of an undifferentiated infec- tious disease. Far be it from me to claim anything that justly belongs to another.

So far as I can find, there has been no claim made by me of "discovery." Nor do I wish any honor or credit for publishing observations, strictly objective. If the cases described in the several papers by me are the same as Dr. Sheffield's, there will be honor enough for me in having called the attention of the medical world to his paper of eleven years ago. But as his own letter points out a few of the many differences between his cases and mine, $I$ shall briefly repeat them:

\begin{tabular}{ll}
\multicolumn{1}{c}{ Shemeld's Cases. } & \multicolumn{1}{c}{ Hirshberg's Cases. } \\
Fpidemic. & Syoradic. \\
Children under 14. & Young adults over 18. \\
Rapld pulse. & Slow pulse. \\
Rapid respiration. & Not accelerated. \\
Termination, crisis and lysis. & Gradual (lysis).
\end{tabular}

When I mentioned lack of data, I referred only to additional methods of examination which have crept into our technic in the intervening eleven years.

Leonard Keene Hirshberg.

\section{Esperanto-The International Language.} SaCramento, CaI., Feb. 11, 1907.

To the Editor:-Kindly permit me to suggest and to urge the early establishment in THE JourNaL of a department of Esperanto, on the following grounds:

1. Esperanto is the one and only proposed international language which has successfully borne the scrutiny both of scholars and of men of affairs.

2. The adoption of Esperanto as the international language would be the most powerful promoter of universal peace imag. inable-infinitely more effective than Dreadnaughts or any other kind of "big stick" and immeasurably less expensive. In blood and treasure what does armed peace cost the world?

3. The adoption of Esperanto as the international language would be the most powerful promoter of the diffusion of knowledge of which it is possible to conceive. Free trade in knowledge! The freedom of the vast realm of science and art and literature for a few days' study! That imagination must be dull, indeed, which does not kindle at the thought!

4. A reading knowledge of medical Esperanto could be acquired in a few days by a physician of fair intelligence.

5. The Journai, as the official mouthpiece of the largest organized body of men in the world whose first duty it is to prevent death (and why not death by war as well as death by disease) and whose chief means of preventing death is the diffusion of knowledge, should be among the foremost in the great work so happily begun by Dr. Zamenhof.

W. A. Brigas.

[We willingly give space to the above letter, because we would like to see a universal language, but we fear that the majority of our readers will think that the propaganda of this idea is not the function of a medical journal.-ED.]

\section{A Summary of the Therapeutic Field.}

New York, Feb. 5, 1907.

To the Editor:-Dr. J. W. Robinson, McCammon, Idaho, has kindly called my attention to two inaccuracies in my address, published in THE Journal Sept. 1, 1906. (1) Nitrous acid should read nitrous oxid. (2) The sentence stating that chemically scopolamin is the same as atropin, etc., should read it is the same as hyoscin, etc. Other matter explanatory of difference in action of those alkaloids was unintentionally omitted from the typewritten copy, and as I was in Europe when the proof was forwarded I could not correct it.

Thomas F. ReILly.

\section{Not Responsible for Discussion as Published.} Ciricago, Feb. 18, 1907.

To the Editor:-My discussion of Dr. Ohlmacher's paper which was published in the last number of THE Journal was vublished against my desire and without my knowledge. The report of the discussion was not proof read by myself.

JOHN C. HOLLISTER. 